\title{
Steps towards the creation of a Mediterranean Geosciences Union
}

\author{
Attila Çiner ${ }^{1} \cdot$ Nabil Khélifi' $^{2}$ A. M. Celâl Şengör ${ }^{1,3}$ \\ Accepted: 10 February 2022 / Published online: 23 February 2022 \\ (c) The Author(s), under exclusive licence to Springer Nature Switzerland AG 2022
}

Edward Gibbon wrote in 1776, in the first sentence of his great classic, The Decline and Fall of the Roman Empire, "In the second century of the Christian Era, the Empire of Rome comprehended the fairest part of the earth, and the most civilised portion of mankind"; the Mediterranean and its continental frame, roughly co-extensive with Imperium Romanum at its greatest extent in the second century CE, still embrace the qualities that Gibbon ascribed to Rome. It is in this naturally and culturally highly diverse region the science of geology took its first steps and then won many of its decisive victories such as the nappe theory, or the theory of large strike-slip faults, or the theory of terrains of soluble rocks (Fig. 1). Unfortunate political events in the twentieth century did much harm to the intellectual development of this unique region, so full of opportunities for discovery in the earth sciences.

The creation of a unique federation that brings together and represents the Mediterranean geoscience community specialising in earth, planetary and space sciences can heal the clefts, ripped open in the republic of science in our area in the course of exceedingly harmful political developments, by bringing together the scientists in the region to interrogate its wonders and to communicate them to the public, not only in and around the Mediterranean but to the entire humanity, even at its farthest outposts wherever they may be.

Although the main aim of this federation is the scientific understanding of natural phenomena, we are fully aware of the fact that such understanding is the sine qua non of a

Attila Çiner

cinert@itu.edu.tr

1 Eurasia Institute of Earth Sciences, Istanbul Technical University, Istanbul, Turkey

2 Middle East and Africa Program, Springer, a Part of Springer Nature, Heidelberg, Germany

3 Department of Geology, Faculty of Mines, Istanbul Technical University, Istanbul, Turkey liveable and sustainable environment for all living beings on earth. That is why we emphatically reject any ascription to this union of an endeavour of "doing science in service of mankind", because we are convinced that any science, i.e., any attempt to understand Nature, is beneficial to mankind, provided mankind wishes to use it for its good and not for its destruction. Science, like life, is entirely devoid of meaning or values; what makes it meaningful and good is what we make of its results.

In this regard, we planned to establish a large federation for the Mediterranean region that is more influential than any local geoscience society to foster fundamental and applied geoscience research that addresses critical societal and environmental challenges. This organisation's overarching vision is to contribute to humanity's understanding of Nature and hopefully help realise a sustainable future for humanity and the planets it inhabits and will inhabit in not too distant a future.

Mediterranean Geosciences Union (MedGU: https://assoc iation.medgu.org/) was created as a unique federation that brings together and represents the Mediterranean geoscience community specialising in earth, planetary and space sciences. MedGU will be structured along the lines of AGU (American Geophysical Union) and EGU (European Geosciences Union).

In recent years, Nabil Khélifi, the in-house Editor for Springer for the Middle East and Africa, had the opportunity to meet many successful geoscientists from the region. He has realised how difficult it is for many of them to travel to international conferences to show their work and build collaborations. A significant event organised through a single federation representing the geoscience community around the Mediterranean and in the broader MENA region could be of enormous benefit.

The creation of this union will give the earth sciences more influence in policy-making and in implementing solutions to preserve the natural environment and create more sustainable societies. Membership is open to individuals who have a professional engagement with the earth, 


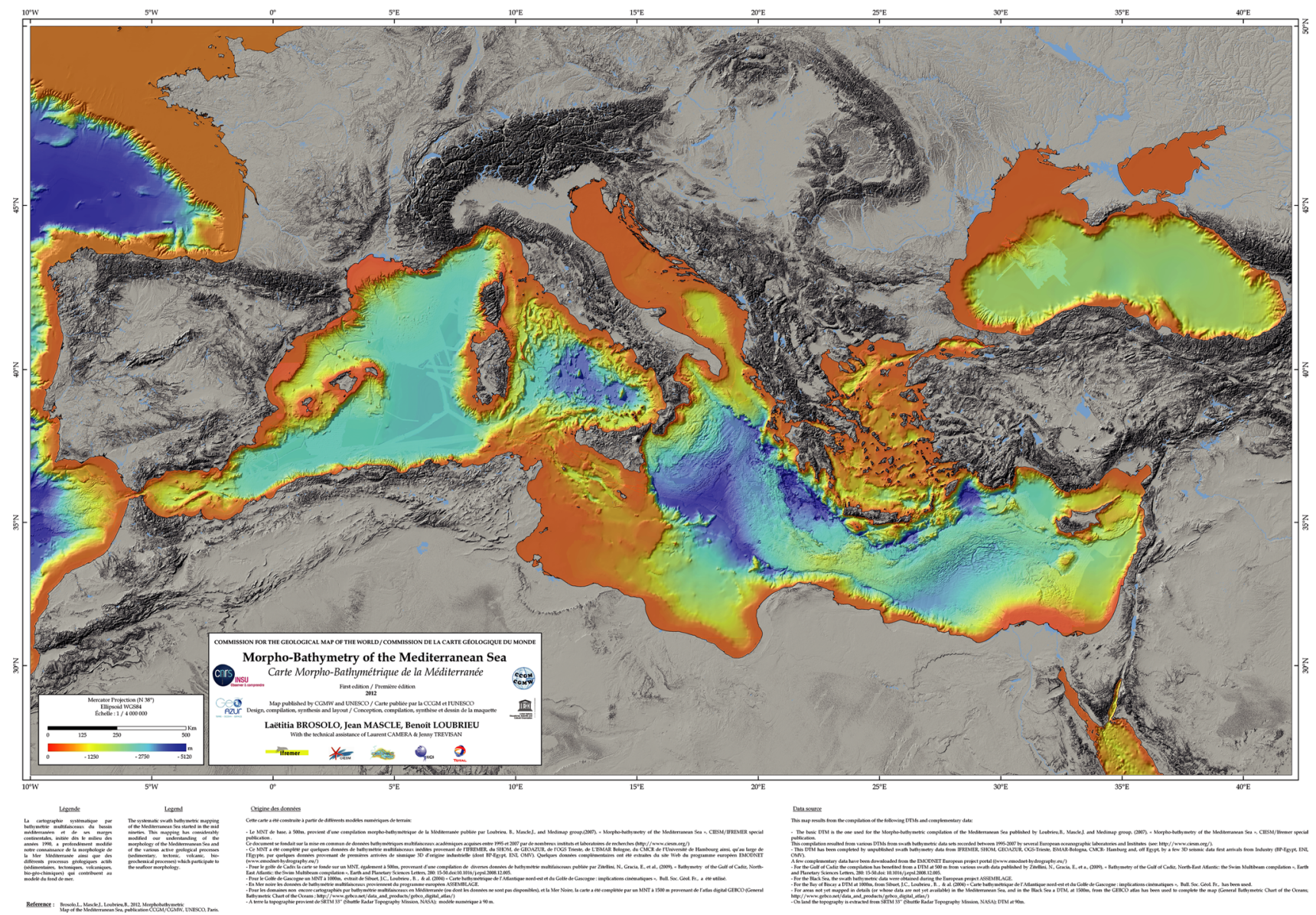

Fig. 1 The Morpho-bathymetric map of the Mediterranean Sea and surrounding regions. The map displays a contrasting view between the continental reliefs, shown in shades of grey, and the Mediterra-

planetary and space sciences and related studies, including students and retired seniors. MedGU plans to recognise the work of the most active geoscientists with several awards and medals.

MedGU inaugural meeting was held in November 2021 in Istanbul (website: https://www.medgu.org/2021) and provided the first forum to achieve a consensus for forming this non-profit international union of geoscientists. More than 450 scientists (200 in-person, 250 online) from over 90 countries have attended the meeting, making it one of the region's largest and most prominent geosciences events.

Nabil Khélifi (Founder of MedGU and Supervisor of MedGU-21) and Attila Çiner (Interim President of MedGU and Chairman of MedGU-21), together with A.M. Celâl Şengör as Honorary Chairman of MedGU-21, have taken an ambitious approach to launch the first MedGU Annual Meeting 2021. They hope to develop it in the near future in collaboration with other Mediterranean scientists into the most significant international geoscience event in the nean seafloor morphology in colour grading scale. Map by Brosolo et al. (2012)

Mediterranean and the broader Middle East-North Africa (MENA) region. Its mission is to support geoscientists in this region by establishing a global geoscience congress.

Springer, the official partner of MedGU, agreed to publish MedGU's proceedings in a book series (indexed in Scopus) and a number of special issues in diverse scientific journals, including the official journal of the meeting, the Mediterranean Geoscience Reviews.

Our aim is thus to create a unique federation that brings together the Mediterranean geoscience community. MedGU's overarching vision is to contribute to the realisation of a sustainable future for the people living in the Mediterranean region, sensu lato. We hope that the Union will provide opportunities for Mediterranean geoscientists to communicate with one another more efficiently and expediently and undertake much-needed interdisciplinary collaborative research. 


\section{Reference}

Brosolo L, Mascle J, Mascle B (2012) Morpho-bathymetry of the Mediterranean Sea; 1:4.000.000 scale. Commission for the geological map of the world
Publisher's Note Springer Nature remains neutral with regard to jurisdictional claims in published maps and institutional affiliations. 